\title{
From Educational Segregation to Transformative Inclusion
}

\section{Cristina Petreñas, Ignasi Puigdellívol, and Roger Campdepadrós}

\begin{abstract}
Recent studies conducted in Europe using communicative methodology highlight that different ways of grouping students has a direct effect on their academic output. This article analyzes how said research methodology identifies and analyzes those student groupings that provide greater academic success and improve classroom coexistence at Spanish educational centers. Said methodology entails all of the research participantsresearchers, teachers, families, and students-reflecting on the consequences of streaming, mixture, and inclusion for student academic achievement. Following this, our conclusions are compared with the policies and educational practices implemented in Spanish schools, which are not based on scientific knowledge and do not usually lead to academic success. Finally, recommendations are presented for future educational policies with the aim of providing an alternative for teachers and educational managers that would substantially improve student academic success.
\end{abstract}

Keywords: communicative methodology of research, educational segregation, streaming, social exclusion, inclusion, INCLUD-ED, MIXTRIN

\section{Introduction}

The educational segregation of students with learning difficulties and those in disadvantaged situations has perpetuated social inequalities over generations. This segregation occurs through educational practices that consist of providing a deficit education to more needful students. Some of these segregation practices are held through homogeneous ability grouping, which entails reducing the curriculum of those students with more educational and social difficulties. These practices, based on deficit theory, reproduce educational barriers faced by many children. 
This research shows the effects of different forms of student grouping in educational achievement, providing evidence of those ways of grouping that lead to educational success for all students. Thus, with the help of scientific literature and communicative methodology, the aim of this article is to demonstrate that it possible to attain rigorous knowledge, based on scientific evidence, of how classroom organization leads to maximizing the academic output of all students. In this sense, an analysis shows those educational experiences that provide the best academic results were conducted from the communicative perspective.

Dialogue among all the subjects involved-students, teachers, family membersresults in a reflection process in which they construct both the interpretation and the analysis that lead to identifying those factors that create improvements and transformations of their environment and lives (Gómez, Siles, \& Tejedor, 2012), as evidenced by the research presented in this article.

\section{Grouping Students in the Classroom Through Communicative Methodology}

Methods of Grouping Found in Europe

The INCLUD-ED ${ }^{1}$ project reviewed educational actions in the European Union that contribute to lower levels of school failure and social exclusion. It analyzed the most recent educational systems and reforms as well as data from international evaluations of EU education systems. It therefore identified educational actions that were providing the best academic results, those contributing to the educational success and social inclusion of all children.

We find two keys to academic success in the ways students are grouped and existing resources used. We have identified three ways of organizing the classroom: mixture, streaming, and inclusion. Mixture refers to assigning a large heterogeneous group of students to one classroom, with only one adult. In this kind of grouping, teachers have to cease giving attention to some students because they are not capable of attending to everyone. This affects the learning of all students in the class, regardless of whether they are more or less capable, and they do not learn as quickly or efficiently as in other classroom dynamics. Students who cannot follow the explanations get bored and become involved in other activities not related to the subject matter or the lesson. This, in turn, can distract other students and hinder progress.

Streaming refers to a homogeneous grouping of students according to their abilities and degree of learning. ${ }^{2}$ This kind of grouping is the result of one teacher 
alone being unable to properly attend to all students. It follows the assumption that said dynamic makes it easier to handle a large group of students with similar characteristics, explain content to the class, and set up and conduct classroom exercises. As we shall see, however, the consequence is that those students labeled as "slow students" and grouped in the "slow classrooms" or "slow groups" fall behind and fail. There are three different kinds of streaming, all of which lead to some students learning more than others. Specifically, those that learn more enjoy better facilities, more material, or are asked to work with greater intensity. Those students who have more difficulty following curriculum requirements, on the other hand, receive specific individual or group teaching outside the regular classroom. First, there is streaming by content, where different classrooms study different subjects. Second, there is streaming by level, where different classrooms study similar subjects but with different levels of difficulty. And third, there is streaming inside the classroom, where students are grouped according to their degree of ability.

An inclusive organization of students overcomes the weaknesses inherent in mixture and streaming, however. According to this approach, students are grouped heterogeneously in the same classroom, preventing exclusion and ensuring all students' participation in the whole learning process, which differentiates it from streaming. In addition, inclusion entails bringing enough material and human resources into the classroom to ensure the success of all students instead of partially or totally excluding some of them. This is the main feature that differentiates inclusion from mixture (INCLUD-ED, 2009). Table 1 summarizes the main features of different student groupings in the classroom based on whether groups are heterogeneous or homogeneous, have one or more teachers, and whether students are together or separate.

This research has represented a great scientific advance in studying ways of overcoming educational exclusion. However, as Betts \& Shkolnik (2000) point out, further in-depth research is still required, particularly because of difficulties in determining the effects of grouping on student achievement. These authors highlight, among other factors, different ways of measuring abilities, the lack of clarity regarding ability levels in classrooms, the fact that surveys do not differentiate between ability grouping and tracking, that the literature has not taken into account the possibility of grouping inside the classroom, that even though a school would not officially group by level, sometimes it does so unofficially, or that it has to take into account how resources are assigned-for instance, whether students of a lesser ability have less qualified or less experienced teachers. 
Table 1: Principal features of different ways of organizing classrooms

\begin{tabular}{|c|c|c|c|c|}
\hline & Mixture & Streaming & \multicolumn{2}{|c|}{ Inclusion } \\
\hline Based on & $\begin{array}{l}\text { Equal } \\
\text { opportunities }\end{array}$ & Differences & \multicolumn{2}{|c|}{$\begin{array}{l}\text { Achieving the same results } \\
\text { and respecting differences }\end{array}$} \\
\hline $\begin{array}{l}\text { Group } \\
\text { composition }\end{array}$ & Heterogeneous & Homogeneous & \multicolumn{2}{|l|}{ Heterogeneous } \\
\hline $\begin{array}{l}\text { Resources } \\
\text { used }\end{array}$ & One teacher & $\begin{array}{l}\text { More than one } \\
\text { teacher }\end{array}$ & \multicolumn{2}{|c|}{ More than one teacher } \\
\hline \multirow{2}{*}{$\begin{array}{l}\text { All together } \\
\text { or separated }\end{array}$} & Together & Separated & Together & Separated \\
\hline & $\begin{array}{l}\text { Mixed ability } \\
\text { classrooms }\end{array}$ & $\begin{array}{l}\text { Classroom activities } \\
\text { are organized } \\
\text { according to ability } \\
\text { level: } \\
\text { - Ability groups in } \\
\text { different } \\
\text { classrooms } \\
\text { - Ability groups in } \\
\text { the same } \\
\text { classroom }\end{array}$ & $\begin{array}{l}\text { Heterogeneous } \\
\text { ability classrooms } \\
\text { with reallocation } \\
\text { of resources }\end{array}$ & $\begin{array}{l}\text { Inclusive } \\
\text { split } \\
\text { classes } \\
\text { with } \\
\text { mixed- } \\
\text { ability } \\
\text { students }\end{array}$ \\
\hline & & $\begin{array}{l}\text { Remedial groups } \\
\text { and support are } \\
\text { segregated from the } \\
\text { regular classroom }\end{array}$ & & \\
\hline
\end{tabular}

Source: INCLUD-ED 2009

\section{From Segregating to Inclusive Practices in Spain}

Spain has a specific educational context within Europe. According to PISA reports, it is among the last ranked positions regarding academic output. Educational policies are among some of the causes for this. Until 1990, compulsory schooling was only up to the age of 14, and Spain had one of the highest illiteracy rates in Europe. In 1970, an education law ${ }^{3}$ established two pathways in secondary education: a vocational training pathway that would lead to manual, semi- or low-qualified work, most of which would become obsolete with the emergence of the information society, and an academic pathway that would lead to university, to the more qualified jobs, and would provide training more appropriate to modern times. A lot of working- and 
lower-class students chose or were oriented toward vocational training, which hindered their social mobility, while rich or middle-class students were oriented toward high school and university, promoting their upward social mobility (Flecha, 1990). In this context, mixture was the prevailing method of classroom grouping. From 1990 onward, with the arrival of LOGSE, ${ }^{4}$ there was a diversification of pathways and emphasis was placed on attending to diversity, even if mainly through streaming practices. In the early ' 90 s, however, some primary and secondary schools began to implement inclusion practices through the Learning Communities project.

After two decades of LOGSE implementation, some researchers have analyzed the effects of this act on student grouping. Both the INCLUD-ED and MIXTRIN ${ }^{5}$ projects had taken an in-depth look at mixture, streaming, and inclusion practices in Spain, providing us with details of the kinds of grouping prevalent in the country and their consequences for student academic achievement. The main goal of these studies was to collect evidence of both academic output and classroom coexistence being improved in centers implementing successful actions endorsed by the international scientific community.

On the one hand, the research detected some educational practices that were generating different kinds of exclusion: level grouping inside the classroom, "support" provided outside the classroom during teaching hours, separation by levels in different classrooms, and, finally, "exclusionary electivity," which often appears in the form of differentiated "pathways." On the other hand, some practices were detected that were generating academic success and improving classroom coexistence: heterogeneous grouping accompanied by other ways of organizing the classroom and human resources, increasing time dedicated to learning, and individual inclusive curriculum adaptation.

One of the first exclusion practices we would like to highlight is grouping by level within the classroom. This is usually done through curriculum adaptation, which consists in less content and lowering demands and expectations for those students who have more difficulties learning. Differences are dealt with via curriculum adaptation, or lightening the curricular load. ${ }^{6}$ These educational actions are usually justified on the basis of student emotional well-being, contrasting it with instrumental learning, which is an entirely Manichaean comparison; it has also been conceptualized and denounced as a "happiness curriculum" (Aubert, Flecha, García, Flecha, \& Racionero, 2008). Results show that this "privilege" of personalized treatment, when accompanied with a lighter curriculum, leads to lower academic achievement.

A prior step to this grouping is the diagnosis and labeling of those students who have difficulties or are "problematic." One of the first findings at the school with 
learning structured according to the streaming method was that groups comprising students with difficulties were informally labeled with or given negative connotations. Teachers and professionals diagnose abilities as experts from a position of power, prescribing students' needs-curriculum adaptations, extra support, etc.without taking into account what the students' families know and think (Sheldon, 2003; Swick \& Hooks, 2005). Teachers often use their position of power to justify ways of grouping through pedagogical arguments with no scientific basis (Braddock \& Slavin, 1992; Lindsay, 2007; Terwel, 2005). Schools do not always make rational choices based on goals; other considerations often come into play, such as institutional and bureaucratic habit, systemic logics, teachers' schedules, or the weight of traditional ways of organizing the classroom and distributing resources. The aforementioned research even found cases of teachers being aware that their decisions would lead to lower academic achievement.

Another exclusionary practice found in Spanish schools is support provided outside the classroom during teaching hours. This consists in specific teaching provided to students having difficulties following curriculum requirements, while the rest of the students follow the planned regular activity, working on other material, usually at a higher level. There can be individual or group support for students with similar learning deficits. Nonetheless, as some families have pointed out in interviews, removing students from the classroom during instrumental teaching hours is counterproductive because they lose track of those subjects. This, in turn, adds to or maintains certain kinds of learning deficits and disadvantages in relation to the rest of the students.

Another practice that separates students by level of abilities and skills is grouping in different classrooms. However, this consolidates student labeling and the assignment of unequal content and demands, which are higher for the more advantaged and lower for the more disadvantaged, maintaining and deepening inequalities between them. This leads to the highly insulting label of "the soft heads' classroom" or "the retards' classroom," perfectly demonstrating educational exclusion and institutionalizing social distinction even further.

Students are grouped and distributed in different classrooms according to their academic output and achievements and different abilities. This can be permanent or temporary and for all subjects or only some. Mobility from one group to another is possible, but usually infrequent; it is the exception rather than the norm. This grouping is a response to the need traditional ways of organizing the classroom create in teachers; that is, the need to have homogeneous students of a similar level, making it easier to explain content, set up exercises, and assess them. This grouping method 
entails teaching specific materials to each group with different content and levels of difficulty. Different learning goals are also assigned to the different groups-lower goals for low performing groups and higher goals for high performing groups.

The last method of exclusionary grouping we have highlighted is that of exclusionary electivity. This consists of asking students to choose from different subjects according to their tastes, abilities, and preferences. The exclusionary feature consists in the fact that choosing one subject or another entails learning different competences and areas of the curriculum, which affects subsequent academic opportunities. Some subjects can lead to a manual and low-qualified vocational pathway, which will make it difficult to move toward a more academic pathway later, while others make it easier to access university and meet the high demands of university learning. However, the aforementioned research also collected data and evidence from schools implementing ways of organizing classrooms that lead to high academic achievement: heterogeneous grouping with reallocation of human resources, extended learning time, and individual inclusive curriculum adaptation.

Heterogeneous grouping with reallocation of human resources consists in maintaining all students of the same age in the same classroom, regardless of different abilities, competence levels, capacities, or previous knowledge. This is similar to the mixture method, which also keeps students of the same age in the same classroom. The difference, however, is that the inclusion method organizes the classroom and assigns resources differently than the traditional one to achieve academic success for all students and accelerate the learning of those students that present more difficulties and disadvantages. One way of achieving this is through interactive groups. ${ }^{7}$ This means organizing students into groups of five or six and assigning an adult to each group. This adult mentors and supports the students so that all of them can understand explanations, solve problems and assignments, and receive the highest quality learning experience. The main goal is to stimulate interaction between students to solve the proposed tasks. The teacher prepares activities and coordinates each session. He or she endeavors to ensure as much heterogeneity as possible within groups, breaking with the traditional exclusion of grouping by levels and abilities. Heterogeneity shifts from being a problem for the teacher to being an activity that enriches the group learning process. The more able and trained students, who finish tasks earlier, help the students with more difficulties. By doing this, the former bolster their learning and the latter finish the task within the stipulated time. In this way, the students with more difficulties are not left behind and the more able students are not affected; rather, they all increase their level and learning. Another way to attend to diversity is to provide specific support for the more disadvantaged students but 
keeping them inside the classroom doing regular activities, never segregating them in other classrooms or spaces.

The success of this kind of grouping is detailed in several studies (Aubert et al., 2008; Elboj \& Niemelä, 2010; Elboj, Puigdellívol, Soler Gallart, \& Valls, 2002; Padrós, García, de Mello, \& Molina, 2011) and in some research using communicative methodology, such as the INCLUD-ED (INCLUD-ED, 2009) or MIXTRIN (CREA, 20092011) projects. The latter project highlights several instances of success, such as a teachers' discussion group that says volunteers' participation improves student coexistence in the classroom as well as their motivation and eagerness to learn. Another example is found in an interview with a Roma mother who explains how two students who used to fight have begun to cooperate in their learning, helping each other out.

Even though this mother had not finished compulsory education herself, her cultural intelligence grasped the principle of nonmethodological inequality between studies and studied subjects (Gómez, Latorre, Sánchez, \& Flecha, 2006). Likewise, antiracist principles lead us to recognize the cultural heritage of the Roma community, which brings a very important added value to the learning process. Like the teacher, the mother from the Roma community also analyzed this reality and contributed her interpretation through a dialogue with the researcher.

The aforementioned research confirms transformations, as is the case with an adolescent who suffered segregation in his previous learning because of his low level of education but who later made a huge improvement because the classroom was organized in an inclusive way and because the school shifted from a minimum curriculum to a maximum expectations curriculum. Through communicative research, students are able to highlight the positive aspects of heterogeneous grouping. The student is given some ideas by the researcher and then considers the suitability of heterogeneous grouping, where interaction between more and less advanced students favors the whole group. With this methodology, we see how throughout the conversation emphasis shifts from quantity of previous knowledge or level of intelligence to motivation; interviewed students shift from speaking about "the soft heads" to the "repeaters who are trying to learn."

The reality created by different kinds of streaming contrasts with evidence given by a teacher regarding the case of a student with Down syndrome who received support in the classroom that allowed him to work on the same content as the rest of his group. In said classroom, students with special educational needs managed to advance in the same content as their classmates; at the same time, their classmates' learning was enriched by this kind of interaction. Such a contrast points to the most 
important component in academic success likely being the proper organization of educational attention, in this case support, and expectations placed on students, rather than their abilities or disabilities.

Another way of accelerating learning for more disadvantaged students is by extending their study time. In addition to attending regular lessons and activities, they attend extra classes to allow them to overcome difficulties and gain the abilities required to follow regular classes. This corrects the error of taking students out of their regular classes, which leads to greater incidence of failure, and helps them achieve the same pace and level as their classmates.

The last method of inclusive organization we have highlighted is individual inclusive adaptation. In this situation, students' learning in one or more subjects is modified compared with that received by the group in order to facilitate their achieving the same pace and level of content as their classmates. Learning goals are not reduced or eliminated, however, especially in instrumental areas. Adaptations are not based on students' difficulties other than those caused by a disability, nor is students' learning rhythm adapted to these difficulties. The learning process is monitored in an endeavor to meet stipulated goals.

\section{Evidence-Based Policy}

All too often, educational practices have been founded on policies whose main concern was not improving student academic achievement. Consequently, they have often provided nothing but failure for a significant number of students. These policies were usually a response to teachers' interests or to the commercial interests of companies supported by one political party or another. However, research into the effects of different educational practices on academic achievement ratified by the international scientific community can be useful for teachers, educational professionals, and politicians in promoting best educational practices. Such research provides evidence regarding which educational practices improve and hinder student learning. To attain a more egalitarian, better educated, and cohesive society, educational policies need to based on the aforementioned scientific evidence. At the same time, this would also prevent them from being based on arguments and hidden interests other than those of improving student academic achievement.

Even today, many educational policies and practices do not achieve educational success and are not based on scientific ideas. Qualitative research from both the INCLUD-ED and MIXTRIN projects has shown that some educational practices are being implemented with no scientific evidence of their being the best option, and 
even in the knowledge that they lower student academic achievement. Furthermore, the MIXTRIN survey showed that most Spanish schools organize classrooms based on streaming. One reason is that teachers and politicians know of no alternatives for both attending to heterogeneity in levels and achieving success for all students, or alternatives that provide both quality and equality. Concretely, they do not know about inclusion as an efficient way of organizing human resources. Aspects such as this highlight the importance of training educational professionals in alternatives that have demonstrated educational success and improved student coexistence in schools. Equally, to achieve greater academic success and overcome school failure, future educational policies might have a scientific base, as the European Commission and other public administrations have proposed through several nonbinding resolutions. ${ }^{8}$ Nowadays, political recommendations exist in Europe to show which actions educational systems might implement to provide an effective response to society's needs without additional resources.

Research in this field (INCLUD-ED, 2009) has detected a series of policies, based on scientific evidence, that improve students' schooling and learning. Concretely, they achieve this by linking (a) the supplementary human resources in interactive groups to successful results; (b) the substitution of segregation practices into inclusive practices to the improvement of disadvantaged groups, such as immigrant students, students from cultural minorities, and students with disabilities; (c) the substitution of segregation practices into inclusive practices to more multicultural groups of students, overcoming ghettoization; (d) good academic achievement to high expectations toward children and youth; and (e) the role of teachers and their methods to promote inclusive practices in the classroom for the achievement of good results.

Likewise, schools with students from low socioeconomic and minority backgrounds that have successful results link good academic achievement to community participation. They achieve this by linking (a) the participation of community members in decision making processes, in the students' learning activities, and in evaluation to successful results; (b) the participation of community members in basic education programs for the community to successful results; (c) the participation of community members to successful results and greater student coexistence; (d) the inclusion of voices from the different cultures in planning the instrumental areas (math, language, etc.) to successful results; (e) community participation to overcoming gender stereotypes and improving academic results; and (f) participation of "other women" (nonacademic women who have been historically silenced from mainstream feminist discourse) to academic success and greater student coexistence. 
Several of these practices entail or are related to inclusive ways of organizing learning. Here we present several general recommendations for organizing classrooms and schools that have been proposed in Spain, together with relevant evidence, taking into account the results of the MIXTRIN project.

First, the MIXTRIN project reiterates the finding that inclusive educational actions lead to educational excellence and equality for all students while streaming practices generate inequalities in students of different levels, competences, or characteristics. The MIXTRIN survey reveals how streaming practices prevail in Spain, while inclusion practices are in the minority. Therefore, it would be sensible to remove streaming practices and stop providing teachers with guidelines for their implementation. Guidelines for inclusion should be provided instead. All segregation based on previous learning levels should be avoided, as should goal adaptation and content and activities that exclude students from the official curriculum.

Second, the project shows how teachers implement streaming practices as a way of attending to diversity but not as a way of achieving the best educational results. They also ignore the most effective and equitable alternatives to attending to diversity. Schools that have implemented inclusive practices have experienced notable improvements in academic achievement. Therefore, an educational policy and teacher training based on scientific evidence and practices that have proved to be the most effective are required to promote learning for all students. It is possible to have quality and equality at the same time, while also attending to diversity, by properly organizing current spaces and resources.

Third, it highlights the fact that the same number of human resources can be used to implement streaming or inclusion. Attending to diversity does not depend on the quantity of resources but in the way these are organized. Therefore, the criteria for actions implemented at schools would be based on research proving their effectiveness.

And, finally, it points out that opening schools to the community allows the introduction of a wide and diverse range of human resources, which favors the implementation of inclusive practices. Consequently, the transformation of schools into Learning Communities must be supported, and community participation in schools must be promoted.

\section{Conclusions}

In this article we wished to highlight the importance of social research aimed at overcoming educational and social inequalities. In this context, communicative 
methodology is proving to be a highly efficient and appropriate tool. It allows us to identify which educational practices are more effective and lead to greater inclusion. The goal of the communicative approach is to improve reality with scientific statements reached through intersubjective dialogue between experts and protagonists of the studied reality. This is carried out from an egalitarian standpoint, that is, stating validity claims about problematic situations such as reproducing segregation in schools. The evidence gathered in the aforementioned fieldwork not only ratifies the findings of the scientific literature but also furthers our knowledge, contributing transformative elements that researchers would not be able to determine alone. On the other hand, dialogue permits current practices to be redefined, looking to improve reality and generate transformations in schools and in the lives of people participating in the research. Furthermore, the voices of groups hitherto excluded from this research are being reinforced and legitimated (Gómez, Racionero, \& Sordé, 2010).

Communicative research has highlighted how schools implementing inclusive organization methods obtain better results with the same resources, thereby becoming points of reference in their communities. It also shows us how to use current resources and scientific knowledge to improve educational practices in daily school life. Transformation processes start from a science based on evidence, and this knowledge is offered to society. Schools that assume these actions in their practices are making a commitment to scientific findings. This improves people's lives and the standard of living of the most vulnerable groups in society (Puigvert, Christou, \& Holford, 2012). Educational policies and practices need scientific evidence that sheds light on how to best group students and the best educational practices for attending to diversity (CREA, 2006-2011). As the fieldwork has shown, when actions are based on intuition rather than evidence, they achieve the contrary effect to the one desired. And as questionnaires from schools have shown, this situation is widespread in Spain.

Such evidence means these practices are of interest to public administration and is the reason why they must guide educational and social policies. Finally, we can add that communicative research permits dialogue between accumulated current scientific knowledge, people's practical knowledge, and the richness of the lifeworlds of people who know their reality first hand. Consequently, it permits and generates a better understanding of reality, which in turn favors the design of more efficient policies for resolving the issues of most concern to the educational community and society as a whole.

Inclusive schools were initially promoted in the field of disabled students' learning and their use was later extended to create equality. They incorporate diversity and 
provide a model of school based on educational quality for all students, emphasizing attention to groups at risk of marginalization, exclusion, or school failure (Ainscow, 1999). Inclusion is understood as shared education and as the sense of belonging to the same group, overcoming traditional practices of separation based on levels of educational attainment (Stainback \& Stainback, 1990). Inclusive schools, therefore, focus on identifying and eliminating the social and educational barriers facing students by substituting the deficit perspective, which is centered on the individual, for the competence perspective, which is centered on examining the limits of school provision. It is important to acknowledge that the increasing diversity found in European schools makes successful inclusive interventions a challenge, and this is therefore a question that requires further research, particularly in relation to the effectiveness of educational practices designed to overcome social inequalities.

\section{Notes}

1. INCLUD-ED, Strategies for Inclusion and Social Cohesion in Europe from Education (2006- 2011), is the only integrated project on school education within the Sixth Framework Program of European Commission.

2. These segregation practices were outlawed in 1985 in Finland, the European country with the best academic results according to the PISA report (INCLUDED, 2009).

3. Act 14/1970, of 4 August, on General Education and Funding for Educational Reform.

4. Educational reform was promoted by the socialist government through the LOGSE Act, Ley Orgánica General del Sistema Educativo, 3 October 1990.

5 . Formas de agrupación del alumnado y su relación con el éxito escolar: Mixture, Streaming y Inclusion, (2009-2011), R+D+i National Plan. This project studied a representative sample of state schools, 366 primary and 316 secondary. It also conducted a qualitative study in five schools implementing streaming or inclusion methods of organizing the classroom. In total, 10 in-depth interviews were conducted with teachers, 10 communicative stories of daily life, four discussion groups with teachers and students, and communicative observations.

6. The civil rights movement in the United States denounced the use of pseudoscientific arguments in special education to hide segregation practices. Dunn (1968) denounced this in his famous review that special classes for "educable mental retarded" (EMR) only included black and Hispanic children. So both 
special classes and EMR conceptualization were tools of segregation. More recent research highlights the over-representation of disadvantaged cultural and linguistic groups in special education (Klingner et al., 2005). In Spain, we can find practices close to streaming in most of the autonomous regions that have not explicitly prohibited the level grouping system.

7. Reduced groups (five to six students), usually monitored by volunteers, perform rotationally different tasks in 15 to 20 minutes on a certain area of the curriculum. The teacher prepares activities and coordinates the class. The essential goal of volunteers (families, community members, university students, etc.) is to stimulate interaction between students to solve the proposed tasks and assignments. The class can last between 60 and 90 minutes (Elboj, Puigdellívol, Soler Gallart, \& Valls, 2002).

8. European Commission Resolution on the reduction of school dropout, 30 January 2011, which refers to Learning Communities (p. 7); European Commission Resolution, 7 June 2011, which refers to reducing school absenteeism via Learning Communities (p. 15); European Commission, 2 April 2009, regarding immigrant children education; Objetivos Educativos Europeos y Españoles. Estrategia Educación y Formación 2020. Informe Español 2010-2011. Informe del Ministerio de Educación de España, which refers to Learning Communities in the Basque Country (p. 92); decree of 15 February 2003 by the Aragón Department of Education and Science, authorizing the introduction of Learning Communities; framework document on Learning Communities by the Catalan Government's Department of Education; and solicitude protocol and actions within the transformation process of schools into Learning Communities by the II Catalan Government's Department of Education.

\section{References}

Ainscow, M. (1999). Understanding the development of inclusive schools. London: Routledge Falmer.

Aubert, A., Flecha, A., García, C., Flecha, R., \& Racionero, S. (2008). Aprendizaje dialógico en la sociedad de la información. Barcelona: Hipatia.

Betts, J. R., \& Shkolnik, J. L. (2000). Key difficulties in identifying the effects of ability grouping on student achievement. Economics of Education Review, 19, 21-26. doi: 10.1016/S02727757(99)00022-9

Braddock, J. H., \& Slavin, R. E. (1992). Why ability grouping must end: Achieving excellence and equity in American education. Baltimore: Center for Research on Effective Schooling for Disadvantaged Students. 
CREA. (2006-2011). INCLUD-ED. Strategies for inclusion and social cohesion in Europe from education. Sixth Framework Program of the European Commission.

CREA. (2009-2011). Formas de agrupación del alumnado y su relación con el éxito escolar: 'Mixture', 'Streaming' e Inclusión (MIXTRIN). Plan Nacional I+D+i. Secretaría de Estado de Universidades e Investigación. Ministerio de Educación y Ciencia.

Dunn, L. M. (1968). Special education for the mildly retarded-is much of it justifiable? Exceptional Children, 35, 5-22.

Elboj, C., \& Niemelä, R. (2010). Sub-communities of mutual learners in the classroom: The case of interactive groups. Revista de Psicodidáctica, 15, 177-189.

Elboj, C., Puigdellívol, I., Soler Gallart, M., \& Valls, R. (2002). Comunidades de aprendizaje. Transformar la educación. Barcelona: Graó.

Flecha, R. (1990). La nueva desigualdad cultural. Barcelona: El Roure.

Gómez, A., Racionero, S., \& Sordé, T. (2010). Ten years of critical communicative methodology. International Review of Qualitative Research, 3, 17-43.

Gómez, A., Siles, G., \& Tejedor, M. (2012). Contribuyendo a la transformación social a través de la metodología comunicativa de investigación. Qualitative Research in Education, 1, 36-57. doi: 10.4471 /qre.201 2.02

Gómez, J., Latorre, A., Sánchez, M., \& Flecha, R. (2006). Metodología comunicativa crítica. Barcelona: Hipatia.

INCLUD-ED. (2009). Actions for success in schools in Europe. Brussels, Belgium: European Commission.

Klingner, J. K., Artiles, A. J., Kozleski, E., Harry, B., Zion, S., Tate, W., Riley, D. (2005). Addressing the disproportionate representation of culturally and linguistically diverse students in special education through culturally responsive educational systems. Education Policy Analysis Archives, 13(38), 1-39.

Lindsay, G. (2007). Educational psychology and the effectiveness of inclusive education/mainstreaming. British Journal of Educational Psychology, 77, 1-24. doi: 10.1348/ 000709906 X156881

OECD. (2010). PISA 2009 Results: What Students Know and Can Do: Student Performance in Reading, Mathematics and Science (Vol. 1). PISA: OECD Publishing. doi: 10.1787/ 9789264091450-en

Padrós, M., García, R., de Mello, R., \& Molina, S. (2011). Contrasting scientific knowledge with knowledge from the lifeworld: The dialogic inclusion contract. Qualitative Inquiry, 17, 304-312. doi: 10.1177/1077800410397809

Puigvert, L., Christou, M., \& Holford, J. (2012). Critical communicative methodology: Including vulnerable voices in research through dialogue. Cambridge Journal of Education, 42, 513-526. doi: 10.1080/0305764X.2012.733341

Sheldon, S. B. (2003). Linking school-family-community partnerships in urban elementary schools to student achievement on state tests. Urban Review, 35, 149-165.

Stainback, W., \& Stainback, S. (Eds.) (1990). Support networks for inclusive schooling: Independent integrated education. Baltimore: Paul H. Brookes.

Swick, K. J., \& Hooks, L. (2005). Parental experiences and beliefs regarding inclusive placements of their special needs children. Early Childhood Education Journal, 32, 397-402. doi: 10.1007/s10643-005-0011-9

Terwel, J. (2005). Curriculum differentiation: Multiple perspectives and developments in education. Journal of Curriculum Studies, 37, 653-670. doi: 10.1080/00220270500231850 


\section{About the Authors}

Cristina Petreñas is a Ph.D. candidate at the University of Barcelona. She has a Ph.D. scholarship funded by the Ministry of Education of Spain at the Department of Didactics and Educational Organization. She is researcher at CREA. Her main research interests are didactics, teacher training, educational psychology, and secondary education. CREAUniversity of Barcelona. Passeig de la Vall d'Hebron, 171. Edifici de Llevant, planta 0. Despatx | 2- 13. 08035 Barcelona. E-mail: cristinapetrenas@ub.edu

Ignasi Puigdellivol holds a Ph.D. in educational sciences from the University of Barcelona (UB) and is a professor in the Department of Didactics and Educational Organization. He was dean at the Teacher College of this university. His main research area is inclusive education, particularly special needs and minority groups. Campus Mundet (UB). Edifici Llevant, 2a Planta. Pg. Vall d'Hebron, 17I. 08035-Barcelona. E-mail: ipuigdellivol@ub.edu Roger Campdepadrós holds a Ph.D. in sociology from the University of Málaga and is an associate professor in the Department of Business at the University of Girona. His main research areas are social integration of migrants in host societies and the role of social networks. University of Girona, c/ Universitat de Girona, 10 - 17071- Girona. E-mail: roger.campdepadros@udg.edu 